\title{
LEVELS OF REVIEW IN AMERICAN EQUAL PROTECTION AND UNDER THE CHARTER*
}

\author{
JUNE ROSS**
}

\begin{abstract}
The author examines American law dealing with equal protection analysis and the possible application of such guidelines to s. 15 of the Charter. The concept and function of levels of review in the United States are discussed. The author concludes that levels of review have performed important definitional, flexibility and predictability functions in American jurisprudence and that such functions may also be performed in our Charter analysis if the American experience and theory is applied.
\end{abstract}

\section{INTRODUCTION}

It is well known that American equal protection analysis is characterized by levels of review. Certain types of equality are seen as meriting special judicial protection; others exist only at the discretion of legislative bodies (provided such discretion is "rationally" exercised). As Canadian courts are faced with a new challenge in the form of $\mathrm{s} .15$ of the Canadian Charter of Rights and Freedoms (the "Charter"), and are required for the first time to apply a substantive equal protection analysis to federal and provincial laws, it is to be expected that they will look to the American experience for guidelines or, at least, to avoid pitfalls.' It is certain that Canadian courts, like American courts before them, will conclude that in many cases legislative line-drawing must be left to the legislatures, while in others judicial intervention is required by the constitutional mandate. The difficulty is to identify the extent of judicial review called for in a particular equal protection challenge; ranging from one extreme of complete deference to legislative opinion, to the other of substitution of judicial opinion for legislative opinion. The purpose of this paper is to examine the concept of levels of review as it is employed in United States jurisprudence to define the required degree of review in a particular case, and to consider the applicability and usefulness of such a concept to fulfill the same role in the context of the Charter. It is concluded that levels of review perform three separate functions in American case law. They define the scope of equal protection. They provide flexibility in equal protection analysis. Levels of review also contribute to predictability of result, although this function to some extent operates in conflict with the flexibility function, and appears to be subordinate to it in recent decisions. An examination of the structure of s. 15 in light of the rules for interpretation of the Charter indicates that levels of review may usefully contribute to s. 15 analysis in the provision of flexibility and predictability. However, structural differences between the Charter and the American Bill of Rights, particularly the

- This article was presented at a series of seminars on s. 15 of the Charter sponsored by the Friends of the Faculty of Law.

** Sessional Instructor, Faculty of Law, University of Alberta; Partner in firm of Witten Binder, Edmonton, Alberta.

1. Two assumptions are made: first, that $s$. 15 requires a substantive equal protection analysis; and second, that Canadian courts will be prepared to refer to United States jurisprudence. Neither assumption is controversial. In Re McDonald and The Queen (1985) 16 C.R.R. 361 at 380, the Ontario Court of Appeal held that $\mathrm{s} .15$ provides for equality in the substance of the law. Many Charter decisions, including Supreme Court of Canada decisions, have considered American case law. 
presence of the Charter's s. 1, make the concept inappropriate as an indicator of the definitional limits of s. 15.

\section{EQUAL PROTECTION ANALYSIS IN THE UNITED STATES}

Traditionally equal protection analysis in the United States adopted a two-tiered approach. Over the last decade and a half this traditional approach has been modified and new tiers or levels of scrutiny have been added to the analysis.

\section{A. TWO-TIERED ANALYSIS}

\section{Minimum Rationality}

Pursuant to the two-tiered approach, every legislative classification must pass a minimum rationality test. The equal protection clause requires that similarly circumstanced persons be treated alike, while persons who are different may be treated differently. In theory the minimum rationality test supports the principle of equality in its most general form. Arbitrary classifications are prohibited and only legislative classifications rationally related to legitimate state goals survive. But an examination of the practical application of the test demonstrates that its support of a general equality principle is only theoretical. ${ }^{2}$

In determining whether or not the minimum rationality test is met, the United States Supreme Court has held that legislatures must have a substantial latitude to establish classifications that roughly approximate perceived problems and accommodate competing concerns, particularly where social or economic legislation is involved. In assessing, therefore, whether legislative classifications are rationally related to legitimate state interests, the Court has assumed legislation to be valid, and has placed the burden of proof to establish invalidity upon a challenger. Further, the Court has been prepared to speculate as to state interests, and has not confined its inquiry to alleged interests or to interests established on the court record. A challenged classification has not been required to be closely related to any state interest. In the traditional application of the test, all that needed to be shown was that a conceivably rational relationship could exist between the classification and a legitimate end. The scrutiny of the Court was "minimal ... in theory and virtually none in fact." ${ }^{3}$

The deferential approach to the minimum rationality test developed as a purposeful reaction by the Court to the perceived dangers of government by the judiciary. The same test and approach also evolved in other areas of

2. A review of Supreme Court authorities to 1979 revealed that only once since the 1930 's had the Supreme Court struck down, under this test, a classification that was part of socioeconomic regulatory scheme, and that decision was subsequently overruled: M.J. Perry, "Modern Equal Protection: A Conceptualization and Appraisal" (1979) 79 Col. L. Rev. 1023 at 1070 . The author concludes that "[a]s a practical matter ... the rationality requirement is largely inconsequential as a constraint on the power of government."

3. G. Gunther, "Foreword: In Search of Evolving Doctrine on a Changing Court: A Model for a Newer Equal Protection" (1972) 86 Harv. L. Rev. 1 at 8. See also: Plyler v. Doe, 72 L. Ed. 2d 786 at 798-99 (1982); Cleburne v. Cleburne Living Center, 87 L. Ed. $2 d 313$ at 320 (1985); and see generally L.H. Tribe, American Constitutional Law (1978) 994-996; G. Gunther, Constitutional Law Cases and Materials (10th ed. 1980) 670-71. 
American constitutional jurisprudence. Minimum rationality is required with regard to all aspects of legislation affecting life, liberty or property. This basic rationality requirement is what remains of the Court's early doctrine of substantive due process, as applied to social and economic legislation that does not impinge upon fundamental constitutional rights. In this context, as well, the test developed as a method to prevent what was considered to be excessive judicial interference. ${ }^{4}$

\section{Strict Scrutiny}

The second tier of traditional equal protection analysis is the strict scrutiny test. This test is applied where legislation impinges upon fundamental rights or disadvantages a suspect class. The former aspect of strict scrutiny equal protection has been called the "right to equal treatment", and the latter the "right to treatment as an equal."s The United States Supreme Court applies a considerably greater degree of judicial scrutiny to state legislation in these cases due to potential conflicts with "elemental constitutional premises."

\section{(a) Suspect Classifications}

Suspect classes include race, alienage, and national origin. These characteristics are considered by the Court to be so seldom relevant to legitimate state interests that legislative classifications based thereon are presumed to reflect invidious discrimination, unless proved otherwise. The burden resting on a party supporting such legislation is onerous: to establish that the classification is precisely and narrowly tailored to serve a compelling state interest; a test "strict" in theory and "fatal" in fact."

The traditional justification for labelling certain classes as suspect is found in Stone J.'s footnote 4 in U.S. v. Carolene Products Co. ${ }^{8}$ The text of the judgment dealt with the minimum rationality test in the substantive due process area. However, in the famous footnote Stone J. suggested that a more exacting judicial scrutiny might be called for where legislation is found to embody "prejudice against discrete and insular minorities" and where, because of this prejudice, "the operation of those political processes ordinarily to be relied upon to protect minorities" has been curtailed. ${ }^{9}$

4. Tribe, supra n. 3 at $996-1000$; Gunther, supra n. 3 at 667 . From the 1905 decision in Lochner v. New York, 49 L. Ed. 937 until the mid-1930's the United States Supreme Court invalidated a number of state regulations of prices and labour relations and other economic and social welfare legislation, by invoking equal protection or substantive due process arguments. These decisions provoked extreme judicial and political dissent, and eventually the Court withdrew from its interventionist stance, through the mechanism of an extremely deferential minimum rationality standard employed in testing the validity of economic legislation.

5. Tribe, supra n. 3 at $992-993$.

6. Plyler v. Doe, supra n. 3 at 799. See generally Tribe, supra n. 3 at 1000-03, 1010-12; Gunther, supra n. 3 at 745-53, 908-10.

7. Gunther, "Foreword", supra n. 3.

8. 304 U.S. 144 (1938).

9. Id. at n. 4 . 
The Supreme Court has enunciated a number of criteria that are involved in determining whether a particular class is suspect, including:

1. A clàss history of purposeful unequal treatment; ${ }^{10}$

2. Immutability of the trait that distinguishes the class;"

3. Present political powerlessness of the class; ${ }^{12}$

4. Existence of stereotyped class characteristics unrelated to the class's abilities to participate in society, that result in the imposition of unique disabilities upon the class. ${ }^{13}$

This list of criteria does not appear to be exhaustive, and the cases do not elucidate their relative importance. No single factor conclusively determines suspect status, rather the decisions appear to rest on an accumulation of the indicia in a particular group. Determination of suspectness is relatively simple where all or virtually all of the criteria are present, as in the cases of race and national origin. However, significantly more difficulty is presented where one or more but not all indicators are present, as in the cases of gender and illegitimacy. ${ }^{14}$

As an example, sex discrimination has on one occasion been characterized by a plurality judgment of the Supreme Court as a suspect classification. Subsequent sex discrimination decisions have withdrawn from that position, and have required only intermediate scrutiny. The precise nature of this scrutiny remains open to debate.

In Frontiero v. Richardson, 's a statute permitting servicemen to claim wives as dependents automatically, while requiring that husbands of servicewomen must show actual dependence, was struck down under the equal protection clause. The plurality judgment, rendered by Brennan J., labelled sex a suspect class meriting strict scrutiny, for the following reasons:

1. The long and unfortunate history of sex discrimination;

2. The tradition of "romantic paternalism" resulting in statutes which are laden with out-moded stereotyped distinctions between the sexes;

3. The continuing existence of sex discrimination;

4. The fact that sex is an immutable characteristic determined solely by accident of birth which generally bears no relation to ability to perform or contribute to society, such that the imposition of special disabilities due to sex violates the basic concept that legal burdens should bear some relationship to individual responsibility or ability.

Three years later, in Craig v. Boren,${ }^{16}$ the Court retreated from the plurality position in Frontiero, while nonetheless striking down a state

10. San Antonio Ind. School Dist. v. Rodriguez, 36 L. Ed. 2 d 16 at 40 (1973).

11. Frontiero v. Richardson, 36 L. Ed. $2 d 583$ at 592-93 (1973).

12. San Antonio Ind. School Dist. v. Rodriguez, supra n. 10.

13. Id.; Frontiero v. Richardson, supra n. 11; Massachusetts Bd. of Retirement v. Murgia, $49 \mathrm{~L}$. Ed. 2d 520 at 525 (1976); Cleburne v. Cleburne Living Centre, supra n. 3 at 321-22.

14. D.R. Widin, "Suspect Classifications: A Suspect Analysis" (1982-83) 87 Dick. L. Rev. 407; P. Weidner, "The Equal Protection Clause: The Continuing Search for Judicial Standards" (1979-80) 57 U. Det. J. Urban L. 867.

15. Supra n. 11.

16. 51 L. Ed. $2 d 574$ (1976). 
prohibition on the sale of $3.2 \%$ beer to males under 21 or females under 18 . The opinion of the Court was again rendered by Brennan J. Without referring to "suspectness" or strict scrutiny, he held that gender classifications must serve important government objectives and be substantially related to their achievement. Rehnquist J., in dissent, distinguished between discrimination against men and discrimination against women. Men as a class do not possess any of the characteristics of usual suspect classifications and therefore, he argued, discrimination against men does not warrant any review other than the traditional minimal rationality test.

In two 1981 cases, the plurality decision or opinion of the Court was written by Rehnquist J. In Michael M. v. Superior Court, ${ }^{17}$ a California rape law that applied to men only was upheld. The plurality decision applied a rationality test, purportedly "with a sharper focus". Pursuant to such a test, Rehnquist $J$. held that laws which are based upon stereotypes, or invidious discrimination, should be struck down, while laws based upon real differences, reflecting valid state interests and a sufficient means/end relationship, should be upheld. The same approach was followed in the opinion of the Court in Rostker v. Goldberg, ${ }^{18}$ upholding the requirement for military registration of males only.

In the following year, the Court decided in Mississippi University for Women v. Hogen ${ }^{19}$ that a state supported university's policy excluding males from enrollment in a professional nursing school was violative of the equal protection clause. The opinion of the court was rendered by $\mathrm{O}^{\prime}$ Connor J., and applied a heightened level of scrutiny, specifically holding that this level of review applied equally to discrimination against men and discrimination against women.

In summary, the current status of judicial review of sex discrimination reveals two prevalent theories. One theory applies heightened scrutiny requiring means substantially related to important government ends to all gender-based discrimination. The second theory supports a rationality test "with a sharpened focus". There are also suggestions that a distinction should be drawn between discrimination against women and discrimination against men. The concept of sex as a suspect class appears to have disappeared, despite the rationale for it discussed in Frontiero v. Richardson.

The sex discrimination example points out two particular difficulties associated with the suspect class concept: that it has not been cogently defined, and that it is inherently one-sided, applying logically to women, but not men, or blacks, but not whites. Both of these characteristics, and particularly the latter, may limit the usefulness of the suspect class concept in interpreting the Charter. The prohibited grounds of discrimination expressly listed in s. 15(1) are all described in neutral terms: "race", as opposed to "minority racial groups"; and "sex", as opposed to "women". Further, s. 15(2) deals expressly with affirmative action, and it may therefore be assumed that forms of "benign" discrimination not protected by s. 15(2) were intended to be prohibited by s. 15(1). In
17. 67 L. Ed. $2 d 437$ (1981).
18. 69 L. Ed. $2 d 478$ (1981).
19. 73 L. Ed. $2 d 1090$ (1982). 
addition, the requirement of present political powerlessness does not accord with the Charter's history, as inclusion of some of the listed grounds (eg., mental or physical disability), can be considered to be evidence of the lobbying power of affected groups. However, some of the criteria of a suspect class, such as the existence of stereotyping and the imposition of disabilities unrelated to actual capabilities, could certainly be considered to reflect a form of mischief intended to be remedied by the anti-discrimination provision of s.15(1). As such, the interpretation of the section should be guided by a consideration of this purpose. ${ }^{20}$

\section{(b) Fundamental Rights}

The strict scrutiny test also applies where legislative classifications affect fundamental rights. The United States Supreme Court has held that fundamental rights are not simply substantial or important individual interests, but rights which are explicitly or implicitly protected in the Constitution apart from the equal protection clause. ${ }^{21}$ The "right to equal treatment" may thus be characterized as collateral to other substantive guarantees, rather than a substantive right in and of itself. It has been suggested that the strict scrutiny of classifications impinging on fundamental rights does not properly form a part of equal protection analysis, as any deprivation of such rights, discriminatory or otherwise, would be protected by virtue of the substantive explicit or implicit guarantees of those rights in the Constitution, apart from the effect of the equal protection clause. $^{22}$

\section{B. INTERMEDIATE LEVELS OF REVIEW}

Since the early 1970's the two-tiered structure of equal protection analysis has broken down. In its place have arisen certain intermediate levels of scrutiny, sometimes referred to as some form of "heightened" scrutiny and at other times referred to as rationality review, but applied in a very different manner than the traditional minimum rationality test. Examples of both heightened scrutiny and strict rationality review in the area of gender-based discrimination have already been discussed. Cases of discrimination based upon illegitimacy display even less consistency, although some intermediate level scrutiny is apparently applied..$^{23}$

Both the two-tiered approach to equal protection analysis, and the new approach involving intermediate levels of scrutiny, are subject to criticism, the former for its rigidity and the latter for reasons set out below. Current equal protection analysis in the United States involves a large degree of uncertainty, as it is not clear what "quasi-fundamental rights" or "quasisuspect classes" will give rise to an intermediate level of scrutiny, or precisely what the intermediate level will be. Sometimes a "heightened review" has been specified, calling for an important government interest,

20. Hunter v. Southam Inc. (1984) 11 D.L.R. (4th) 641 at $650-51$ (S.C.C.).

21. San Antonio Ind. School Dist. v. Rodriguez, supra n. 10.

22. Perry, supra n. 2.

23. Mills v. Hableutzel, 71 L. Ed. $2 d 770$ (1982) requiring a "substantial" relation to a "legitimate" state interest; and cases reviewed in Gunther, supra n. 3 at 897-908. 
and means substantially related to that interest. However, the test has been phrased in a number of different ways. ${ }^{24}$ Further, the cases in which the Court has not acknowledged that it was applying a heightened level of review, but purportedly applied a rationality test to strike down legislation, make it especially difficult to determine the reason for or degree of review.

Certain of the justices on the Court have also rejected the approach to equal protection analysis involving discrete levels of review, claiming that it does not accurately describe the Court's decisions in this area, nor adequately take into account all proper factors and considerations. Marshall J. has supported a "sliding scale" of review, in which the level of review in any particular case depends upon the degree of constitutional and societal importance of the individual interest affected, and the invidiousness of the basis of the challenged classification. Marshall J. claims that it is unrealistic to attempt to categorize these elements into two, three or any given number of levels of review, and that it should be recognized that each case will demonstrate its own degrees of importance and invidiousness. ${ }^{25}$

Stevens $\mathrm{J}$. is similarly of the view that the decisions show a continuum of judgmental responses to different classifications and that the stated standards or levels of scrutiny do not properly represent that continuum. However, Stevens J. asserts that the rational basis test has sufficient flexibility to be applied in all circumstances..$^{26}$ The basic difference between the approaches of Marshall and Stevens JJ. is that the former advocates a continuum of legal tests, to be defined and established by precedent as cases arise, while the latter advocates a single test at law, and a continuum in the factual application of that test.

An examination of two recent Supreme Court cases dealing with intermediate levels of review will demonstrate some of the difficulties of equal protection analysis, the differing approaches to it, and the resulting uncertainty and unpredictability. In Plyler v. Doe, ${ }^{27}$ a Texas statute withholding funds from local school districts for education of children not legally admitted into the United States, and authorizing school districts to deny enrollment to such children, was held violative of the equal protection clause. The opinion of the Court, given by Brennan J., with Marshall, Blackmun, Powell and Stevens JJ. joining, held that undocumented aliens were not a suspect class because undocumented status was not a "constitutional irrelevancy". Further, education was not a fundamental right guaranteed by the Constitution. Strict scrutiny was therefore not appropriate. Nevertheless, because the legislation imposed a discriminatory burden on children who were not responsible for their own status, and because denial of education would significantly affect the children, the Court held that this was an area of "special constitutional sensitivity" and invalidated

24. Widin, supra $\mathrm{n} .14$, in $\mathrm{n} .17$ gives examples of range of phraseology used to express tests within the intermediate level of review.

25. See the decisions of Marshall J. in Cleburne v. Cleburne Living Centre, supra n. 3; Plyler v. Doe, supra n. 3; San Antonio Ind. School Dist. v. Rodriguez, supra n. 10; and Dandridge v. Williams, 25 L. Ed. 2d 491 (1970).

26. See the decisions of Stevens J. in Cleburne v. Cleburne Living Centre, supra n. 3; U.S. Railroad Retirement Bd. v. Fritz, 66 L. Ed. 2 d 368 (1980); Craig v. Boren, supra n. 16.

27. Supra n. 3. 
the legislation on the ground that it did not further a "substantial state goal". 28

The Court's opinion thus applied an intermediate level of scrutiny. However, there are indications in the judgment that, in other contexts, undocumented status might require nothing more than rationality review. ${ }^{29}$ It appears that the combination of a quasi-fundamental right and a quasisuspect status gave rise to heightened review. This is the first and to date only instance in which a majority of the Court has employed a middle level of analysis based upon a balancing of these two factors. ${ }^{30}$

Three of the members of the Court who joined in the opinion of Brennan J. also filed separate reasons, demonstrating substantial variations in approach. Marshall J. confirmed his view that a sliding scale of review should be applied in all equal protection cases. Blackmun J. indicated that the nature of the interest at stake in the case, as opposed to the nature of the class, was the crucial element. Powell J., on the other hand, held that heightened review was required because of the basis of the classification.

The dissenting justices applied a traditional two-tiered analysis. As no suspect class or fundamental right was involved, they considered that the Court's inquiry should be limited to a minimum rationality test.

In Cleburne v. Cleburne Living Centre, ${ }^{31}$ a city ordinance requiring a special use permit for a group home for the mentally retarded was held invalid as applied in the case. The opinion of the Court was written by White J., and joined in by Burger C.J., and Powell, Rehnquist, Stevens and $\mathrm{O}$ 'Connor $\mathrm{JJ}$. They held that mental retardation was not a "quasisuspect classification" because, unlike the characteristics of gender or illegitimacy, mental retardation was related to an individual's ability to participate in society, and classifications based upon mental retardation did not generally reflect out-moded stereotypes. Further, the Court found that mental retardation was relevant to legitimate state interests, and that governmental consideration of it was often not only legitimate, but desirable, as evidenced by legislation benefitting mentally retarded individuals. Recent legislative responses to the problems of mental retardation indicated to the Court that this was not a politically powerless group. Finally, and tellingly, the Court was concerned that the class was very large and amorphous, and would be difficult to distinguish from other perhaps immutable disabilities, such as speech, physical disability, mental illness or infirmity.

However, while no heightened review was required, the Court held that this class was not entirely without protection, and proceeded to find that the ordinance as applied was invalid, purportedly employing a rationality test, but applying it in a very different way than the traditional minimum rationality test. The Court found that the record before it did not support the legislative policy decision, or show that there was a relevant distinction in the circumstances of the case between retarded individuals and other

28. Id. at 801-03.

29. Id. at 805 .

30. J.F. Casey, "Plyler v. Doe: The Quasi-Fundamental Right Emerges in Equal Protection Analysis" (1983-84) 19 New Eng. L. Rev. 151.

31. Supra n. 3. 
persons. The Court also challenged certain alleged state interests, such as the promotion of neighbourhood serenity, holding that mere unsubstantiated fear or negative attitudes of the neighbours were not permissible bases for differential treatment of retarded individuals. Such a scrutiny of the legislative purpose, as well as a reliance on the record, and an apparent imposition of a burden on the state to support the ordinance, are all clearly not typical of the rationality test. ${ }^{32}$

Stevens J. joined in the reasons of the Court, but filed separate reasons disputing the levels of review approach to equal protection analysis, and suggesting that the proper approach would be to apply the rationality test in all circumstances. Marshall J., with Brennan and Blackmun JJ., concurring, criticized the Court's judgment, noting that while it purportedly applied a rationality test, in actuality the test as applied amounted to a heightened review. They were concerned that by refusing to acknowledge that something more than minimum rationality review was involved, the Court opened up the possibility of an overly stringent review being applied to economic and commercial classifications, and provided "no principled foundation for determining when more searching inquiry is to be invoked." ${ }^{33}$

The criticisms of Marshall $\mathrm{J}$. are cogent and point to the advantage of a legal, rather than a factual continuum of review. The sliding scale proposed by Marshall J. provides flexibility, but does not abandon the goal of predictability. Where levels of review are established as a matter of law, whether they are discrete or continuous, the effect of judicial precedent will be to provide a greater degree of predictability than could be achieved if the differences between cases are characterized simply as issues of fact. The Cleburne case provides little or no guidance to courts that may have to deal with other classifications based on mental retardation or on other mental or physical disabilities. Only reasons to refrain from judicial review are discussed in the majority opinion. There is no explanation of the characteristics of the class or other factors that motivated judicial intervention.

\section{COMPARISON WITH FIRST AMENDMENT ANALYSIS}

Another area of American constitutional law in which levels of review have developed is the First Amendment protection of freedom of speech. Traditionally, as with equal protection, decisions applying the guarantee of freedom of speech involved a two-pronged approach. Certain types of speech, in particular, political speech, were defined as being within the realm of constitutionally-protected speech, and other types of speech were defined as being outside of that realm. Laws which directly infringed or denied free political speech were struck down unless they were necessary to avoid a "clear and present danger." ${ }^{34}$ The state interest being forwarded by the legislation had to be a particularly compelling one, and the relationship between the legislative means and that objective had to be clear and direct.

32. Id. per the judgment of Marshall J.

33. Id. at 333.

34. Schenck v. U.S., 63 L. Ed. 470 (1919). 
While the test is differently phrased than the strict scrutiny test in the equal protection area, there are obvious similarities.

The traditional approach to freedom of speech also defined certain types of speech as outside the scope of "speech" for First Amendment purposes. These included obscenity ${ }^{35}$ commercial speech, ${ }^{36}$ and a number of other categories, such as "fighting words" ${ }^{37}$ and defamatory speech ${ }^{38}$ However, over the last two decades the Supreme Court has gradually widened the area of constitutionally protected speech, and has correspondingly broadened the range of tests of the legitimacy of legislation. The area of defamation law was constitutionalized, and defamatory speech no longer remained exempt from constitutional scrutiny, although interests in prohibiting defamatory speech, within defined guidelines, continued to receive judicial recognition..$^{39}$ While obscenity as such remains beyond the scope of constitutional protection for the majority of the Court, it has been narrowly defined, and other tests have been developed to test regulation of sexually-oriented speech that does not come within the category of obscenity. ${ }^{40}$

Recently, commercial speech has been recognized as warranting a degree of constitutional protection similar to the intermediate level of scrutiny in the equal protection area. In Virginia Pharmacy Board v. Virginia Consumer Council ${ }^{41}$ the Court struck down a prohibition against advertisement of prescription drugs, holding that speech does not lose its First Amendment protection simply because it is given in a commercial context. However, the commercial/non-commercial distinction remains relevant to the degree of protection. Requirements to legitimately legislate regarding commercial speech were further elaborated in Central Hudson Gas v. Public Service Commission, ${ }^{42}$ as a four-part test:

1. The speech must be lawful and not misleading;

2. The legislation must forward a substantial government interest;

3. The means employed in the legislation must directly advance that interest; and

4. The means employed must be no more extensive than is necessary to serve that interest.

\section{FUNCTIONS OF LEVELS OF REVIEW}

Levels of review in the United States equal protection jurisprudence perform two distinct functions. First of all, they perform a definitional function. This is most clearly seen in the traditional two-tiered analysis in equal protection, especially when that is compared with the traditional analysis in freedom of speech. As noted earlier, the basic minimum

35. Roth v. U.S., 1 L. Ed. 2d 1498 (1957).

36. Valentine v. Chrestensen, 316 U.S. 52 (1942).

37. Chaplinsky v. New Hampshire, 315 U.S. 568 (1942).

38. Beauharnais v. Illinois, 343 U.S. 250 (1952).

39. New York Times v. Sullivan, 11 L. Ed. $2 d 686$ (1964).

40. N.Y. v. Ferber, 73 L. Ed. $2 d 1113$ (1982).

41. 48 L. Ed. $2 d 346$ (1976).

42. 65 L. Ed. $2 d 341$ (1980). 
rationality requirement of equal protection is not particular to the equal protection clause, but is seen in other areas of American constitutional law as a general requirement for rationality of legislative action. The requirement is aptly called a "minimum" rationality test, as it has only a minimal practical import. At least for practical purposes, and arguably for theoretical purposes, cases which merit only application of the traditional minimum rationality test have been defined as being outside the scope of the constitutional guarantee of equal protection. The low level of review defines the limits of the protection, just as the definition of the word "speech" in First Amendment jurisprudence defines the limits of that constitutional protection.

Beyond the traditional minimum rationality requirement, in any case requiring strict scrutiny, or any level of intermediate scrutiny including the modern stringently applied rationality test, one is definitionally within the scope of the equal protection guarantee. In all of these cases, the court is providing a form of judicial review of practical import to litigants that would not be available but for the equal protection clause (sometimes in combination with other substantive constitutional guarantees, as where fundamental rights are involved). Within this area of protection, the second function of levels of review becomes apparent. Levels of review provide flexibility to the court's analysis, allowing it to impose a heavy burden and to look skeptically upon legislation affecting areas of central constitutional importance, while permitting a greater latitude for legislative discretion in other areas of more collateral importance, without totally excluding such areas from any constitutional protection. The most important result of this flexibility is that, with it as an aid, the courts are less inclined to narrowly define the scope of constitutional review. Examples of this are seen in the commercial speech decisions, and in the developing quasi-suspect classifications and quasi-fundamental rights in equal protection. If the courts were confined to a "clear and present danger test" or strict/fatal scrutiny, they would likely not venture into these areas. On the other hand, if only an intermediate level of review were applied in cases of racial discrimination or prohibitions against political speech, permitting a broader degree of legislative discretion, the court could be accused of failing to properly and zealously protect these crucial areas.

The definitional and flexibility functions of levels of review are realized to a reasonable degree in the jurisprudence. Another function of levels of review is the provision of predictability as to the degree of review to be provided in a particular case. This function has not been well realized in the equal protection jurisprudence to date, at least partly because the jurisprudence is at a stage of considerable development, with the relatively recent introduction of intermediate levels of review. Further, there is to some extent an inherent conflict between the need for flexibility and the need for predictability. Marshall J.'s sliding scale of review may provide somewhat greater flexibility and less predictability, at the expense of flexibility, if agreement can be reached as to the number and nature of such levels. However, the differences between these two approaches are minor, compared with their similarities. Obviously, levels of review in either discrete or continuous form contribute to flexibility. Further, as discussed 
above, the establishment of legal levels of review of either form is more conducive to producing predictable results than a factual case-by-case approach.

\section{APPLICATION OF LEVELS OF REVIEW ANALYSIS TO THE CHARTER}

Can American equal protection analysis, particularly in view of its apparent problems, be usefully applied in interpretation of s. 15 of the Charter? In considering this, we should keep in mind the caveat of the Supreme Court of Canada in the recent decision of Reference re Section 94(2) of the Motor Vehicle Act. ${ }^{43}$ The majority decision of Lamer J., considering the application of American procedural due process/substantive due process concepts to the interpretation of $s .7$ of the Charter, made the following comments: ${ }^{44}$

The substantive/procedural dichotomy narrows the issue almost to an all-or-nothing proposition. Moreover, it is largely bound up in the American experience with substantive and procedural due process. It imports into the Canadian context American concepts, terminology and jurisprudence, all of which are inextricably linked to problems concerning the nature and legitimacy of adjudication under the United States Constitution. That Constitution, it must be remembered, has no s. 52 nor has it the internal checks and balances of ss. 1 and 33. We would, in my view, do our own Constitution a disservice to simply allow the American debate to define the issue for us, all the while ignoring the truly fundamental structural differences between the two constitutions. Finally, the dichotomy creates its own set of difficulties by the attempt to distinguish between two concepts whose outer boundaries are not always clear and often tend to overlap. Such difficulties can and should, when possible, be avoided.

Keeping this warning in mind, we go on to consider conflicting principles and concerns in interpretation of the Charter that, in the writer's view, result in a need for levels of review.

\section{A. INTERPRETATION OF THE CHARTER}

With the release of its recent decision in The Queen v. Oakes, ${ }^{45}$ the Supreme Court has now expressly adopted a two stage approach to interpretation of the Charter and has established guidelines to the interpretation of s. 1. These requirements of interpretation, as set down in the Oakes case and previous Supreme Court authority, are as follows:

1. Two stages to interpretation are involved: a stage during which the scope of a guaranteed right is defined; and a subsequent stage, during which the saving provision of $s .1$ is applied; ${ }^{46}$

43. [1986] 1 W.W.R. 481.

44. Id. per Lamer J. at 491 .

45. (1986) 65 N.R. 87.

46. Id. at 123. Dickson C.J., for the majority, refused to apply a rational connection test to interpretation of s. 11(d), holding that "it is highly desirable to keep s. 1 and s. 11(d) analytically distinct." He further noted that "separating the analysis into two components is consistent with the approach this Court has taken to the Charter to date ...", citing R. v. Big $M$ Drug Mart Ltd. (1985) 18 D.L.R. (4th) 321; Hunter v. Southam Inc., supra n. 20; and Law Society of Upper Canada v. Skapinker (1984) 9 D.L.R. (4th) 161. Estey and McIntyre JJ. concurred in the reasons of Dickson C.J. with respect to the relationship between s. 11 (d) and s. 1 . The same approach is notable in Re Singh and Minister of Employment \& Immigration (1985) 17 D.L.R. (4th) 422 per Wilson J.; and in Reference re Section 94(2) of the Motor Vehicle Act, supra n. 43 per Lamer $\mathrm{J}$. 
2. At the first stage interpretation should be generous, to give effect to Charter rights, but not over-generous. Heed should be paid to the specific words of the Charter, the context, and the historic and philosophic background. The Supreme Court has described the required approach as purposive. ${ }^{47}$ Further, at this stage rights and freedoms should not be subjected to implied or judicially-created limitations intended to balance government interests against rights and freedoms. This is at least the case where guaranteed rights or freedoms do not contain inherent limiting words. Otherwise, the clear and express requirements of $s .1$ would be avoided; ${ }^{48}$

3. At the second stage, the onus of proof shifts to the party asserting the limit. The standard of proof required under s. 1 is the civil standard, but rigorously applied. Where evidence is required, it should be cogent and persuasive..$^{99}$

4. The objective of the legislation must be legitimate, in the sense that it must be intra vires the powers of Parliament or the provincial legislature, and must not directly conflict with the protection of Charter rights and freedoms. ${ }^{30}$ Further the objective must be "of sufficient importance to warrant overriding a constitutionally protected right or freedom." "\$1

5. The means chosen by the legislation must be reasonable and demonstrably justified, requiring "a form of proportionality test." Dickson C.J., in the Oakes case, laid down three important components of this test: (1) a rational connection between means and objective; (2) means which impair "as little as possible" rights or freedoms; and (3) balancing of the seriousness and severity of the impairment of rights or freedoms as against the importance of the objective. ${ }^{53}$ While these are the general requirements Dickson C.J.

47. Hunter v. Southam Inc., supra n. 20; R. v. Big M Drug Mart Lid., id.

48. In $R$. v. Oakes, supra n. 45 at 125 , Dickson C.J. held as follows: "It is important to observe at the outset that $\mathrm{s} .1$ has two functions: first, it constitutionally guarantees the rights and freedoms set out in the provisions which follow; and, second, it states explicitly the exclusive justificatory criteria (outside of s. 33 of the Constitution Act, 1982) against which limitations on those rights and freedoms must be measured." [Emphasis added.] Note should also be made of the Supreme Court decision of $R$. v. Therens (1985) 18 D.L.R. (4th) 655 in which LeDain J., with the implicit support of the Court on this point, distinguished between the Charter and the Canadian Bill of Rights on the basis that the structure of the Charter requires a different approach to interpretation of the scope or content of a right, and qualification or limitation of that right. Charter rights are expressly made subject to $\mathrm{s}$. 1 . There is therefore no need under the Charter, as there was under the Bill of Rights, to limit a right by the meaning or interpretation placed upon it.

49. R. v. Oakes, supra n. 45 at 126-129; citing Hunter v. Southam Inc., supra n. 20; Law Society of Upper Canada v. Skapinker, supra n. 46; and Re Singh and Minister of Employment \& Immigration, supra n. 46.

50. R. v. Big M Drug Mart Ltd., supra n. 46; A.G. of Quebec v. Quebec Assoc. of Protestant School Bds. (1984) 10 D.L.R. (4th) 321.

51. R. v. Big M Drug Mart Ltd., supra n. 46, cited in R. v. Oakes, supra n. 45 at 129. Mere expediency or convenience has been held not to be a goal of sufficient importance for this purpose: Re Singh and Minister of Employment \& Immigration, supra n. 46.

52. R. v. Big M Drug Mart Ltd., supra n. 46, cited in R. v. Oakes, supra n. 45 at 129.

53. R. v. Oakes, supra n. 45 at $129-130$. 
noted that "the nature of the proportionality test will vary depending on the circumstances." What is required is a balancing of individual or group interests against societal interests. ${ }^{54}$

\section{B. CONFLICTING PRINCIPLES AND CONCERNS}

An examination of cases arising under s. 2(b) of the Charter dealing with freedom of expression in a commercial sense or context, demonstrates a reluctance on the part of the courts to apply fully a s. 1 onus. The Courts have reacted either by applying a less significant onus on the supporter of legislation affecting commercial speech, or by completely excluding commercial speech from constitutional protection.

In Re Law Society of Manitoba and Savino ss the Manitoba Court of Appeal found that Law Society regulations on advertising constituted an infringement of freedom of expression, but was very ready to find such infringement to be reasonable under s. 1. Monnin C.J. held without extensive analysis that "any limitations which may have been placed upon the rights of Mr. Savino to advertise in directories or newspapers, are reasonable limits prescribed by law which in my view are justified". $\mathrm{He}$ was clearly reluctant to have the courts become involved in an extensive s. 1 analysis, stating that "it is not the function of courts to scrutinize the policy of advertising as such. That is the field of the Law Society and the courts must not interfere". Huband J.A. stated simply that "rules regulating advertising within a professional body would normally be regarded as a reasonable limit within the meaning of section 1 of the Charter'. In these judgments there was at most a finding that the Law Society was attempting to forward a legitimate government interest. The importance of that interest was not compared with the infringement of rights, the relationship between means and end was not seriously examined, and the availability of less restrictive alternative means was not even addressed.

In $R$. v. Halpert, ${ }^{36}$ relating to restrictions on offering, advertising or displaying gasoline for retail trade in other than metric units, Hawkins J. of the Ontario County Court held that this restriction on freedom of expression was justified under $\mathbf{s . 1}$. Again, the decision reflects a relatively minimal review under s. 1. Hawkins J. did find a legitimate government objective and a rational connection between that objective and the limitations imposed. However, in doing so he was clearly deferring to Parliament's exercise of discretion:s7

I do not consider it this court's role to try to second guess the duly-elected representatives of the people in Parliament assembled. Parliament has decided that metrification is a "good thing" for Canada. I cannot imagine how that policy could be implemented without the ultimate goal of universality. To permit unbridled freedom of choice would be to Balkanize the country and encourage the dinosaur mentality.

A majority of the Ontario Divisional Court reacted to the conflict between the requirements of $s .1$ and its desire to avoid involvement in the
54. Id. at 129.
55. (1983) 1 D.L.R. (4th) 285 (Man. C.A.).
56. (1984) 48 O.R. 249 (Co.Ct.).
57. Id. at $255-56$. 
area of commercial policy in Re Klein and Law Society of Upper Canada ${ }^{58}$ by concluding that commercial speech should be denied any protection under the Charter. The case involved a challenge to Law Society rules prohibiting fee advertising. Callaghan J. held that the s. 2(b) guarantee of freedom of expression covered only the same freedom of expression that existed prior to the Charter, and therefore applied exclusively to political speech. He distinguished American commercial speech decisions applying intermediate scrutiny as follows: ${ }^{39}$

\begin{abstract}
... the fact that [commercial speech] fell under the First Amendment did not justify the application of the same criteria and tests when judging the legitimacy of its regulations by the government. In other words, the [United States] Supreme Court developed a new set of criteria, unique to commercial speech, to evaluate such regulation. The Supreme Court can do that precisely because the reasonable limits that are built into the U.S. Constitution are judge-made limits. The Charter, on the other hand, with its express provision of a reasonable limits clause in $\mathrm{s}$. 1 , must of necessity preclude such a course of action. The alternative is for the Canadian courts to develop two separate and different interpretations of s. 1, one to be used where political speech is involved, the other where commercial speech is involved. That approach surely invites chaos.... Such an approach would also draw Canadian courts into a case-by-case review of regulation of most forms of commercial expression, a task better left to the people's elected representatives.
\end{abstract}

Henry J., dissenting, applied a two-stage approach and declined to imply limits at the definitional stage, holding that under the Charter no distinction in principle is made between freedom of expression as it may relate to political expression or economic activity. Both the ordinary meaning of the words of s. 2(b) and the interpretive approach to the Charter described above support this conclusion. Henry J. further noted that at the limits stage Charter rights and freedoms are subject to the flexibility provided in $\mathrm{s} .1$.

In spite of the concerns of Callaghan $J$., it is suggested that the dissenting approach involving a flexible or multi-levelled analysis under s. 1 does far less violence to the language of the Charter than the wholesale exclusion of an area of expression from the scope of s. 2(b). Further, the balancing aspect of s. 1 as described in the Oakes case supports the application of different levels of review. Dickson C.J. required reference to the seriousness "in terms of the nature of the right or freedom violated. . . . and the degree to which the measures which impose the limit trench upon the integral principles of a free and democratic society" .60

Without levels of review, the principles relating to interpretation of the Charter, combined with the s. 1 onus, place Canadian courts in a difficult position. They are called upon to generously interpret rights, and to impose a burden on government to justify limitations or infringements. In cases dealing with central constitutional values the $s$. 1 burden is and should be significant. In cases dealing with more collateral issues, that nonetheless come within the scope of a generous definition of the substantive right, the courts hesitate to apply fully the $s .1$ burden. Their reaction, using the commercial speech cases as an example, may be to purport to apply a s. 1 onus, but to do so in a more "relaxed" manner, not

58. (1985) 50 O.R. (2d) 118 (Div. Ct.). Applied in Grier v. Alta. Optometric Assn. [1985] 5 W.W.R. 436 (Alta. Q.B.).

59. Id. at 166-67.

60. R. v. Oakes, supra n. 45 at 130. 
requiring evidence, or not examining in depth the importance of the legislative purpose or proportionality of the means. The unfortunate result of this approach is that it may tend to erode the significance of the s. 1 onus as applied in all circumstances. Another potential judicial reaction is to narrowly define the scope of the constitutional right. The problem with this approach is that the requirement for a generous interpretation of rights is not met, and large areas of legislation, properly within the scope of the Charter, are excluded from any form of constitutional review. One can argue that either reaction is simply wrong, and that Canadian courts should accept the challenge of applying the Charter without "any lingering doubts as to its legitimacy." However, it may equally be argued that these demonstrations of reluctance to interfere reflect valid limits to the scope of judicial review.

Such reactions would not be necessary if levels of review were recognized as a proper part of a s. 1 analysis. The levels could be of a stipulated number, for stipulated circumstances, or could occur on a continuum similar to Marshall J.'s sliding scale. D.C. McDonald J. in Reich v. Alberta College of Physicians and Surgeons appears to prefer the latter approach: ${ }^{62}$

The yardsticks by which the court should judge whether it has been shown that the limitation can be demonstrably justified in terms of the means chosen to achieve the legislative object are that the means and the object must be consistent with the existence of freedom and democracy. "Freedom" is used in the sense of the fundamental freedoms, guaranteed by s. 2, and the other freedoms, described as "rights", which are found throughout the rest of the Charter. If neither freedom nor democracy is diminished by a limitation on a guaranteed right, the court will find itself more easily persuaded that the limitation is demonstrably justified than if either or both of them are diminished by the limitation. Not all limitations on guaranteed rights will adversely affect what is normally regarded as freedom or democracy, or will do so to the same degree, although it would be imprudent now to attempt to identify any particular guaranteed right or set of rights as less likely to affect freedom or democracy. Any such identification or comparison should be made when a particular right is in issue in a concrete case. [Emphasis added.]

The wording of s. 1 appears to be sufficiently broad to allow either type of levels of review. Whether a fixed number of levels or a sliding scale is used, the purpose of flexibility is met and provides a solution to the concerns referred to above.

\section{LEVELS OF REVIEW AND INTERPRETATION OF SECTION 15(1)}

\section{Definitional Function}

Whether or not a levels of review analysis can perform a definitional function with regard to s. 15(1) depends on whether this is interpreted as an inherently qualified right or a right that, before the application of s. 1, is unqualified. The words are capable of either interpretation. A right to equality "without discrimination" could refer to a right to equality

61. Reference re Section 94(2) of the Motor Vehicle Act, supra n. 43 at 491.

62. (1984) 31 Alta. L.R. 205 at 222-23 (Q.B.). 
without the imposition of arbitrary or irrational distinctions ${ }^{63}$ If this were the case guidelines would be needed to determine what distinctions are arbitrary or irrational. These guidelines would have to enable the courts to determine what cases should be of concern under s. 15(1), triggering the court's special supervisory role. When this role is triggered, the guidelines would have to deal with the nature and degree of justification required. An analysis in terms of levels of review could provide these guidelines, just as it does in American equal protection jurisprudence.

Under an unqualified interpretation, a prima facie violation of s. 15(1) would be shown without a demonstration of unreasonableness. All questions of reasonableness would be determined under s. 1. The most extreme position would suggest that any adverse distinction in treatment, or in impact, would bring a challenged law within the definitional scope of s. 15(1) ${ }^{64}$ Thereafter, resort must be had to $\mathrm{s.} 1$, with its attendant burden on the supporter of legislation.

Using this approach, levels of review could not be involved at the interpretive stage, as they are fundamentally inconsistent with the concept of an unqualified right. Further, levels of review could not perform a definitional function at the limits stage. Section 1 clearly requires that some onus be placed upon the supporters of legislation, while the definitional aspect of levels of review involves the reversal of the burden of proof as a means of excluding cases from equal protection review.

In the writer's view, a qualified interpretation of s. 15(1), requiring a showing of unreasonableness, is not consistent with the interpretive principles applicable to the Charter. The very fact that the words of s. 15(1) are capable of an unqualified meaning suggests that any other would deny the requirement for a generous interpretation. Further, the approach renders s. 1 superfluous and denies to s. 15(1) litigants its important procedural and substantive protections. ${ }^{65}$ On the other hand, the courts seem almost certain to reject the alternative interpretation that has been offered. This would involve imposing a s. 1 burden on the government to justify before the courts virtually all legislative classifications, an enormous task which, in the majority of cases, is adequately undertaken by the democratic political process. The reaction of the courts in commercial speech cases indicates they would not be overeager to undertake such a program.

63. This view is espoused by M. Gold, "A Principled Approach to Equality Rights: A Preliminary Inquiry" (1982) 4 S. Ct. L. Rev. 131; Hough, "Human Rights and the Equality Provisions of the Charter", The Canadian Charter of Rights: Law Practice Revolutionized (1982); and Greenawalt, "Equality Theories and Their Results", Paper presented at the National Symposium on Equality Rights (1985). It has been adopted in a number of early Charter cases, including Re Andrews and Law Society of B.C. (1985) 22 D.L.R. (4th) 9 at 16 (B.C.S.C.); R. v. D. (1985) 7 C.R.D. 350.70-04; Weinstein v. Min. of Educ. for B.C. [1985] 5 W.W.R. 724 at 738-39 (B.C.S.C.); and R. v. Hamilton (1985) 17 C.R.R. 153 (Ont. Prov. Ct.).

64. See Lederman, “Human Rights Statutes, International Instruments and the Charter”, Paper presented at the National Symposium on Equality Rights (1985); Bayefsky, "Defining Equality Rights," in Equality Rights and the Canadian Charter of Rights and Freedoms (Bayefsky and Eberts eds. 1985) 1 at 77-79 and R. v. Neely (1985) 7 C.R.D. 350.70-02.

65. Lederman, supra n. 64 at 38-44. 
It would appear that definitional limits must be found, but definitional limits which do not depend upon reasonableness and so do not usurp the function of s. 1. Two possibilities have been suggested in the case law to date. In Smith, Kline \& French Laboratories Ltd. v. A. G. of Canada, ${ }^{\circ 6}$ Strayer J. held that any distinctions based upon specifically enumerated grounds constitute prima facie violations of s. 15 , requiring s. 1 justification. However, with regard to unenumerated grounds, in order to avoid the "floodgates" problem, either intentional discrimination (legislation with a purpose of disadvantaging a person or group) or an irrational classification must be shown before s. 1 is invoked. In the writer's view, while the motivation for this distinction between listed and unlisted grounds is understandable, the distinction is nonetheless not supported by the language of s. 15. The words "in particular", appearing before the listed grounds in s. 15, may give those grounds more weight than others, but they do not justify the application of an entirely different interpretive approach.

A different approach was adopted by D.C. McDonald J. in Kask v. Shimizu. ${ }^{67} \mathrm{He}$ refused to consider rationality in defining the scope of $\mathrm{s}$. 15(1) as applied to either enumerated or unenumerated grounds, holding that such an approach would not give effect to the principles established in the Oakes case. As to the scope of s. 15(1), he held as follows: ${ }^{68}$

What kinds of discrimination, other than those specifically enumerated, would undermine such values? The list of enumerated grounds provides an indication of the complexion of the kinds of discrimination which the framers of the Charter had in mind as being legislative or administrative acts that would undermine such values. They represent two situations. The first consists of grounds that are based on some immutable physical or other characteristic that a person possesses (race, national or ethnic origin, colour, sex, age or mental or physical disability). The second refers to a situation in which a person has a characteristic which is protected by some other Charter-guaranteed right or freedom (religion).

The focus in the foregoing is on the nature of the affected class, as in the American suspect classifications branch of equal protection. Other Charter guarantees are considered only in the context of giving rise to suspect classes, in that classifications based on protected rights and freedoms constitute prima facie discrimination. However, the result in the case appears to depend not on the basis of the classification but on the nature of the affected interest, as in the American fundamental rights decisions. Ms. Kask was challenging a rule of court that provided that an order for security for costs might be issued against an out of province plaintiff. D.C. McDonald J. noted that this might be characterized as discrimination based on either wealth or residence. His $\mathbf{s .} 15$ analysis was undertaken with regard to the former ground only. Wealth is neither an immutable characteristic, nor a characteristic protected by the Charter. Nonetheless, D.C. McDonald J. found prohibited discrimination, due to the value of the particular government service involved. This value was demonstrated by the relationship of the service to the Charter rights and freedoms. Access to civil courts was not held to be the subject of a separate

66. (1985) 7 C.P.R. (3d) 145 (F.C.T.D.). A similar approach is found in R. v. Dupuis (1985) 17 C.R.R. 174 (Ont. Prov. Ct.).

67. Unreported, 11 April 1986, J.D. of Edmonton, 8303-15705 (Alta. Q.B.).

68. Id. at 12-13. 
substantive Charter right; only "equal access" was held to be "implied" in s. 7 and required by s. 15 (emphasis added) ${ }^{69}$ The ratio thus goes further than the current American fundamental rights jurisprudence, relying upon rights that are important, but not necessarily constitutionally protected. On the other hand, the definition of discrimination may not go as far as the full scope of American suspect and quasi-suspect classes which do not necessarily require immutability or constitutional protection of the basis of classification.

Another possible approach to s. 15 is similar to that in the Kask decision, but gives a broader definition of grounds of discrimination, and does not rely upon the fundamental rights notion. This approach would limit s. 15 (1) to cases of distinctions based upon personal characteristics. ${ }^{70}$ "Personal characteristics" are meant to denote individual qualities of the general nature of those listed in s. 15(1), although not limited to the listed categories. Such characteristics are not necessarily immutable, but have some degree of permanence. They constitute attributes of an individual, as opposed to transitory incidents of choice. The dividing line between these concepts will not always be clear. For example, both wealth and occupation involve significant elements of choice, but also a significant degree of permanence, so that they might be considered to be personal attributes. Where classifications are based on characteristics of this type, an intermediate level of review may be appropriate.

This approach is consistent with the language of $s .15(1)$ and, at least arguably, with its philosophic and historic context. It provides a scope of protection generally consistent with anti-discrimination statutes" and with anti-discrimination provisions in international human rights instruments. ${ }^{72}$ It is consistent with the suspect classifications branch of American equal protection, although not with the fundamental rights branch. However, if the latter were confined to rights that receive a separate substantive constitutional protection, it would, in any event, be superfluous. Such a definitional scope to $s .15(1)$ provides limits that substantially narrow the range of legislative classifications calling for judicial review, while still giving full effect to $\mathrm{s} .1$.

\section{Flexibility and Predictability Functions}

Regardless of the interpretive approach adopted, levels of review can provide needed flexibility to $\mathrm{s}$. 15(1) analysis. This function is especially important if an unqualified interpretation is favoured. Without flexibility

69. Id. at 15 .

70. B.C. and Y.T. Bldg. and Construction Trades Council v. A.G.B.C. [1985] 6 W.W.R. 726 at 734-35, 743, limits s. 15 to inequalities based on individual qualities, but also adds an irrationality element, as does Re Andrews and Law Society of B.C., supra n. 63.

71. For example, the Individual's Rights Protection Act, R.S.A. 1980, c. I-2, prohibits discrimination only on specified grounds similar to the listed grounds in s. 15. See generally, Tarnopolsky and Pentney, Discrimination and the Law, Part II, "Prohibited Grounds of Discrimination" (1985).

72. For example, the International Covenant on Civil and Political Rights, adopted Dec. 16, 1966, entered into force Mar. 23, 1976, Article 26, provides that states shall "prohibit any discrimination and guarantee to all persons equal and effective protection against discrimination on any ground such as race, colour, sex, language, religion, political or other opinion, national or social origin, property, birth or other status." [Emphasis added.] 
in the application of s. 1, one could expect the same difficulties to arise in this context as in the commercial speech area. The courts cannot apply the same degree of judicial skepticism to all classifications based on personal characteristics. Some are obviously relevant to proper legislative goals, and necessarily the subject of a degree of legislative discretion so that those goals may be met at least partially or approximately. To refuse to recognize levels of the s. 1 onus in this context would likely result in either an erosion of that onus, or very strict definitional limits.

While levels of review can perform valuable functions under the Charter, we should not feel bound by American conclusions as to appropriate levels in particular cases, or even as to the defining criteria of particular levels. While certain indicia referred to in United States jurisprudence may be useful, others will be inappropriate or at least limited in their relevance due to the wording of the Charter. For instance, as noted earlier, the one-sided approach to analysis of suspect classes, in which only oppressed classes merit strict scrutiny, would not be appropriate in view of the neutrally-defined categories of s. 15(1), and the affirmative action provisions of s. 15(2). The latter may be seen as intended to provide an exclusive answer to problems of benign discrimination. In addition, the very criteria relied on in American jurisprudence, such as patterns of unequal treatment or stigmatization, will result in different conclusions when applied in the Canadian context. For example, with such factors in mind, one would have a better argument for applying strict scrutiny to language distinctions in Canada than in the United States. ${ }^{73}$

Should Charter levels of review be discrete or continuous? In the writer's view, the wording of $s .1$ is sufficiently flexible to permit either approach. The choice therefore depends on their respective usefulness and workability. Clearly the number of levels cannot be overly restricted. The rigidity of the traditional two-tiered equal protection was unworkable. Indeed, it would seem unwise to attempt to limit in advance the precise number of levels of review. The United States Supreme Court appears to be as uncomfortable with three levels as with two, as evidenced by its explicit or implicit adoption of additional intermediate levels of review. Whether referred to as discrete levels or points on a continuum, the levels will eventually achieve a greater or lesser degree of predictability, depending on the nature of the case and judicial precedent. For certain types of cases, such as those dealing with commercial speech, it may be possible to define with relative precision the required degree. In the equal protection area, the level of review for certain types of classifications, involving, for instance, explicit reference to specific listed grounds, may also be capable of a reasonable degree of definition. Other classifications involving unlisted grounds, or differential impact, rather than express classification, will in their nature create a greater degree of uncertainty. The characterization of levels as discrete or continuous does not significantly affect the issue.

In summary, it appears that levels of review, a cornerstone of American equal protection theory, perform important definitional, flexibility and predictability functions in American jurisprudence and can perform at

73. As noted in Paquette v. R. [1986] 3 W.W.R. 232 (Alta. Q.B.). 
least the latter two functions in Charter analysis, even taking into account the structural differences between our constitutions. Provided we do not allow American courts to define the issues or the conclusions, their experience may provide a valuable method for dealing with the problems inherent in providing an interpretation of $s .15(1)$ that is suitably robust without unsuitably usurping the continuing role of Canadian legislatures. 